\title{
Nativised English Lexemes and Semantic Shift in Malaysian English
}

\author{
Nur Fatima Wahida Mohd Nasir ${ }^{1}$ \\ ${ }^{1}$ Academy of Language Studies, UiTM Perak Branch, Seri Iskandar Campus, Malaysia \\ nurfa269@uitm.edu.my \\ Article history: \\ Received: 10 May 2021 \\ Accepted: 27 July 2021 \\ Published: 31 July 2021
}

\begin{abstract}
Research suggests that Malaysian English (ME) is nativised at all linguistic levels and is especially dynamic at the lexical level. Even the standard form of ME demonstrates an inclination for lexical level nativisation in the form of borrowings, loan translations and new English compounds. Most research in ME lexis has mainly focused on identifying and explaining the evolution of the nativised forms. The frequency of these lexical items and their meanings in the context of use however, have not received much research attention. Thus, the current study addresses this gap based on a descriptive cross-sectional research. The data was analysed based on the six categories of lexicalisation in ME including polysemic variation, semantic restriction, informalization, formalization, directional reversal and college colloquialism. The findings suggest that nativised English lexemes in the category of informalization in ME are most common and that respondents agree on the localised meanings of these lexemes. Nonetheless, there is evidence that some words could also have other meanings in ME, suggesting that meanings of nativised English lexemes are continuously shifting.
\end{abstract}

Keywords: Nativised English lexemes, Malaysian English (ME), semantic shift

\section{Introduction}

Nativisation, a notion introduced by Kachru (1983), is a process of linguistic readjustment that a language experiences when used by speakers of different linguistic backgrounds and is a prominent feature in languages that are used in multiethnic and multilinguistic communities. In countries such as Malaysia which have diverse panorama of speech communities, this form of linguistic readjustments is inevitable at all levels of English used by the speakers. In this regard, research has shown that nativisation happens at all linguistic levels in Malaysian English (ME).

According to Azirah and Tan (2012), simplification of linguistic features is what mostly differentiates ME with other New Englishes, especially in terms of grammar and pronunciation, through the switching of diphthongs and monophthongs, frequent stops instead of dental fricatives as well as the simplification of consonant clusters. ME also demonstrates unique distinctive features at the lexical level through creative processes such as borrowings, loan translations and new English compounds (Hajar, 2014; Tan, 2013).

Lexical level nativisation process in ME also includes change in meaning or semantic shift, that is, nativised English lexemes acquiring localised meanings (Thirusanku \& Melor, 2012). According to Menon (2003), these are English words that have lost their original colonial British meanings and have acquired new nonnative meanings. The localisation English word meaning is a process of semantic shift and is a feature of New 


\section{Nur Fatima Wahida Mohd Nasir \\ Nativised English Lexemes and Semantic Shift in Malaysian English}

Englishes' linguistic creativity and meaning construction. Yet, this linguistic phenomenon is underresearched in ME. There is a gap in the ME literature on the extent to which nativised English lexemes in the variety differ in meaning(s) from the native English use.

Another aspect of ME lexis that has not received much research attention is the frequency of nativised English lexemes since most research focuses on the development of nativised English lexemes in relation to issues such as cultural identity, language trend, and language choice (David, 2000; Baskaran, 2005; Azirah \& Tan, 2012; Thirusanku \& Melor, 2012; Pillai, 2013; Kadir, Maros, \& Hamid, 2013; Firooz \& Noraini, 2014; Thurairaj, Hoon, Roy \& Fong, 2015; Yamaguchi \& Deterding, 2016).

Word meaning can change and expand over time as well as, according to speakers and context (Traugott and Dasher, 2002; Lakoff and Johnson, 2003). In the context of new Englishes, semantic shift is not just inevitable, but also necessary as they fulfill the communicative needs of the speakers. Hence the current study focuses on frequently used nativised English lexemes in ME and their meanings in the context of contemporary Malaysia. The findings will therefore, shed light on current trends in the use of nativised English lexemes in ME.

\section{Literature Review}

\section{Semantic shift in New Englishes}

In linguistics, the term lexis designates the complete set of all possible words in a language. It is also regarded as a particular subset of words that are grouped by some specific linguistic criteria (Ruano- García, 2010). With regard to New Englishes, Kachru (2006) argues that the strong influence of localized lexical forms is what reflects a speech community's way of articulation. ME, as with other new varieties of English around the world, also experiences linguistic readjustments at the lexical level due to the contact and influence of local languages in Malaysia.

According to Jackson and Zé Amvela (2000) although nativisation is realized at all linguistic levels, it is usually through lexis that New Englishes best assert themselves. Nativisation at the lexical level includes several creative processes of borrowings, semantic shift, affixation, compounding, clipping, abbreviation, blending and hybrid compounding (Yen, 1990; Menon, 2003; Baskaran, 2005; Traugott, 2006; Vanhove, 2008; Azli, 2010; Hajar, 2011; Azirah \& Tan, 2012; Thirusanku \& Melor, 2012; Grandy, 2012).

Semantic shift is a form of language change which involves the evolution of word or lexeme use in terms of their meaning, when they acquire new meanings that are different from the original usage (Vanhove, 2008). Semantic change over time, can be due to socialcultural forces, psychological forces, linguistic forces, 
institutional and non-instituitional proscriptivism, taboo concepts, flattery, insult, fuzziness, disguising language, aesthetic-formal reasons, communicative-formal reasons, desire for plasticity, anthropological salience of a concept, culture-induced salience of a concept, changes in referents, or worldview changes (Grzega and Schöner, 2007).

Words such as 'awful' and 'gay' are examples of English lexemes that have experienced semantic shift. The word 'awful' originally meant inspiring wonder or fear but is now used to describe something negatively. A more recent example, 'gay', used to refer to joyous, lighthearted, bright and happy but is now used more often to refer to homosexuality (Lalor, 2007).

According to Traugott (2006), semantic shift refers to both the process and product of changes in the meanings. She categorises semantic shift into six types namely, semantic broadening (the meaning of words becomes wider); semantic narrowing (the meaning of words becomes more specific); amelioration (a negative meaning of a word becomes positive); pejoration (a positive meaning of a word becomes negative); metaphor (a process where one aspect of an object is transferred into another object and the later object could deliver an equal meaning); and metonymy ( a word associated with another along the lines of already existing connections).

With regard to nativised English lexemes in ME, Azirah and Tan (2012) proposes six sub-categories of lexicalisation, namely polysemic variation, semantic restriction, informalization, formalization, directional reversal and college colloquialism. The following section discusses these six sub-categories.

\section{Lexicalisation in ME}

\section{Polysemic Variation}

Polysemy essentially refers to two or more words with the same form and related meanings (Yule, 2010). A word such as 'head' is polysemous as it is usually referred to the main top body part of a human, but also has extended meanings such as the top of a glass or a person at the top of a company. In relation to the notion of polysemy therefore, polysemic variation mostly refers to English lexemes that have their native meanings as well as an extended range of other meanings that do not conform to the Standard English (Azirah and Tan, 2012). In ME, the word 'cut' which originally means to slice, has an extended meaning which is to overtake. Besides that, there are also words like 'liase' which means to communicate with another person or organization, but is often regarded more in dealing with another person or organization in ME (Azirah \& Tan, 2012). Table 1 presents other examples of words in the polysemic variation category in ME.

Table 1: Polyesemic Variation of nativised English lexemes in Malaysian English 
Nur Fatima Wahida Mohd Nasir

Nativised English Lexemes and Semantic Shift in Malaysian English

\begin{tabular}{|c|c|c|}
\hline 1. Cut & To slice & To overtake \\
\hline 2. Beat & To hit vigorously & To beat someone in a competiton \\
\hline 3. Liase & To communicate with & To deal with \\
\hline 4. Open & $\begin{array}{l}\text { To allow access, having exposure, to allow } \\
\text { space, to spread out, or an outdoor space, }\end{array}$ & $\begin{array}{l}\text { To draw apart, to turn on electrical } \\
\text { appliances, to remove, or to undress }\end{array}$ \\
\hline 5. Call & To give a specific name or to cry out & To in invite, to ask, to order, or to re-employ \\
\hline 6. Aunty/Uncle & The sister/brother of one's father or mother & $\begin{array}{l}\text { Any elderly person who is an acquaintance } \\
\text { and does not necessarily have family } \\
\text { relationship in order to show respect. }\end{array}$ \\
\hline 7. Occupy & To reside or to to fill in of time and mind & To live in or to take up time \\
\hline 8. Bungalow & A single storey detached house & $\begin{array}{l}\text { A large detached house with more than one } \\
\text { storey }\end{array}$ \\
\hline 9. Shillings & $\begin{array}{l}\text { A former British coin equal to one twentieth } \\
\text { or twleve pence }\end{array}$ & Any unit that is in the form of coins \\
\hline 10. Chase & To pursue, catch up or drive away & To court or woo someone romantically \\
\hline 11. Students & $\begin{array}{l}\text { A person who is studying at school or at a } \\
\text { university }\end{array}$ & $\begin{array}{l}\text { A person who is specifically studying at } \\
\text { school }\end{array}$ \\
\hline 12. Reduce & $\begin{array}{l}\text { To make smaller, or less in amount, degree or } \\
\text { size }\end{array}$ & $\begin{array}{l}\text { To make smaller or less specifically in the } \\
\text { amount of money }\end{array}$ \\
\hline 13. Estate & $\begin{array}{l}\text { A piece of property in the form of land or a } \\
\text { large mansion }\end{array}$ & $\begin{array}{l}\text { A property or land specifically of rubber or } \\
\text { oil plantation }\end{array}$ \\
\hline 14. Theatre & $\begin{array}{l}\text { A hall with a stage for live drama } \\
\text { performances }\end{array}$ & A cinema hall \\
\hline 15. Change & Balance of remaining money at a transaction & Balance money \\
\hline 16. Compound & An enclosed area within army barraks & $\begin{array}{l}\text { An enclosed area around a house or a group } \\
\text { of buildings }\end{array}$ \\
\hline 17. Tupperware & A branded product of plastic containers & Any plastic containers \\
\hline 18. Squat & To sit on a floor & A temporary accommodation \\
\hline 19. Cartoon & An animated show & A comical person \\
\hline 20. Fly & To move through the air using wings & To skip class or school \\
\hline 21. Keep & To have or retain posession of something & To put something away in a pocket or a bag \\
\hline 22. Fix & $\begin{array}{l}\text { To fasten something securely in a particular } \\
\text { place or position }\end{array}$ & To build or put something together \\
\hline
\end{tabular}

Source: Yen, 1990; Menon, 2003; Baskaran, 2005; Azli, 2010; Azirah \& Tan, 2012; Thirusanku \& Melor, 2012; Cambridge Advance Learner's English Dictionary, 2021.

\section{Semantic Restriction}

Semantic restriction or also known as semantic narrowing is another type of semantic shift where the meaning of a word becomes less general or inclusive than its original meaning. This happens when a word with a general meaning is by degree applied to something more specific, such as the word 'hound' which used to refer to dogs in general and not just hunting dogs (Crowley \& Bowern, 2010). Another example is the word 'litter' which referred to 'bed' 1300 years ago, gradually narrowed down to 'bedding' and now used in reference to rubbish (Steinmetz, 2008).

Likewise, semantic restrictions in the case of $\mathrm{ME}$, are words that are used in a narrower sense and is confined to specific referents only. According to Azirah and Tan (2012), English lexemes that have gone through the process of semantic restrictions in ME are words such as 'coffee shop' and 'outstation'. In the Standard 
International Journal of Modern Languages and Applied Linguistics e-ISSN: 2600-7266

English, 'coffee shops' are known as enclosed cafés serving coffee and light refreshments, but in ME the term is mostly implied to open fronted restaurants that serve local food as their main business.

'Outstation' on the other hand is recognized as a branch of an organization situated at some distance away or simply a working place which one does not live in. In ME however, 'outstation' specifically is used when refering to a person who is still in the country but not in the local vicinity (Baskaran, 2005; Azirah \& Tan, 2012). Other words in the category of semantic restriction in ME are presented in Table 2.

Table 2: Semantic Restirction of nativised English lexemes in Malaysia English

\begin{tabular}{|c|l|l|}
\hline \multicolumn{1}{|c|}{ Words } & \multicolumn{1}{|c|}{ Native Meanings } & \multicolumn{1}{|c|}{ Narrower Meannings } \\
\hline 1. Coffee shop & Enclosed cafés serving coffee and light refreshments & $\begin{array}{l}\text { Open fronted restaurants that serve } \\
\text { local food }\end{array}$ \\
\hline 2. Outstation & $\begin{array}{l}\text { A branch of an organization situated at some distance } \\
\text { away or simply a working place which one does not } \\
\text { live in }\end{array}$ & $\begin{array}{l}\text { A person who is still in the country } \\
\text { but not in the local vicinity }\end{array}$ \\
\hline 3. Tuition & $\begin{array}{l}\text { Payment for instruction in an institution of higher } \\
\text { learning and schools }\end{array}$ & $\begin{array}{l}\text { Reinforced teaching with a fee } \\
\text { regarding to school subjects }\end{array}$ \\
\hline 4. Windy & Characterized by or exposed by strong winds & Food that can cause flatulence \\
\hline 5. Heaty & Sensitive to heat & $\begin{array}{l}\text { Food that can cause heat in the } \\
\text { body like spicy and oily curries }\end{array}$ \\
\hline
\end{tabular}

Source: Yen, 1990; Menon, 2003; Baskaran, 2005; Azirah \& Tan, 2012; Cambridge Advance Learner's English Dictionary, 2021.

\section{Informalization}

In linguistics, informalization is linked with informal or colloquial language as the term incorporates aspects of intimate and personal discourse (Fairclough, 2003). Informalization therefore uses shortened terms of address, contractions of negatives and auxiliary verbs, the use of active rather than passive sentence constructions, inclusion of slangs as well as the adoption of regional accents (Baker \& Ellece, 2011).

According to Leech, Hundt, Mair, and Smith (2010), informalization or colloquialism is well-documented in the language of the media, especially in news reportage where there is a definite trend away from the traditional written style and is leaning towards a more spontaneous directness.

Fairclough (2003) further states that it is the most common linguistic and functional style of speech for casual communication, characterized by a wide range of usage of interjections and other expressive devices along with rapid changes in lexicon.

Based on this, Baskaran (2005) states that many lexemes articulated by ME speakers are mostly used within the spoken mesolect level where it is common to find a profusion of lexemes indicating a more informal style and register in ME. Some examples in the category of informalization are presented in Table 3.

Table 3: Informalization of nativised English lexemes in Malaysian English

\begin{tabular}{l|l|l} 
Words & Native Meanings & Informal Meanings/Substitution
\end{tabular}


Nur Fatima Wahida Mohd Nasir

Nativised English Lexemes and Semantic Shift in Malaysian English

\begin{tabular}{|c|c|c|}
\hline 1. Children & A young human being & Kids \\
\hline 2. Husband & A married man & Hubby \\
\hline 3. Spouse & A husband or wife & Partner \\
\hline 4. Brother & A man or a boy in relation & A male waiter or a male friend \\
\hline 5. Flick & A sudden quick movement & To steal \\
\hline 6. Spend & $\begin{array}{l}\text { To give money or to pay for goods and } \\
\text { services }\end{array}$ & Giving a treat to someone \\
\hline 7. Follow & To go or come after & To accompany \\
\hline 8. $\quad$ See & To perceive with eyes & To watch TV or movies \\
\hline 9. Spoilt & $\begin{array}{l}\text { To diminish or destroy the value or quality } \\
\text { of }\end{array}$ & Out of order \\
\hline 10. Sleep & $\begin{array}{l}\text { A condition of body and mind that recurs for } \\
\text { several hours }\end{array}$ & To go to bed \\
\hline 11. Profession & An occupation & Line \\
\hline 12. Fellow & A man or a boy & A person \\
\hline 13. Confused & Unable to think clearly or preoccupied & Blurr \\
\hline 14. Stamp & To impress a pattern or a mark on something & Chop \\
\hline 15. Best & $\begin{array}{l}\text { Of the most excellent or desirable type of } \\
\text { quality }\end{array}$ & Lucky or great \\
\hline 16. Terror & Extreme fear & Terrific or super \\
\hline 17. Power & The ability or capacity to do something & Awesome or great \\
\hline 18. Slumber & A condition of sleep & To feel relaxed or too laid back \\
\hline 19. On & Physically in contact supported by a surface & To agree on an activity \\
\hline 20. Boss & A person who is in charge of an organization & $\begin{array}{l}\text { A CEO, kopitiam waiter, or someone you need } \\
\text { a favour from }\end{array}$ \\
\hline 21. Cable & $\begin{array}{l}\text { A thick rope of wire or hemp used for } \\
\text { construction }\end{array}$ & $\begin{array}{l}\text { Having connections with high and established } \\
\text { organizations }\end{array}$ \\
\hline 22. Action & The fact or process of doing something & $\begin{array}{l}\text { To show-off or a person who is boastful, cocky } \\
\text { and arrogant }\end{array}$ \\
\hline 23. Roger & Used to express assent or understanding & To call someone \\
\hline 24. Settle & To resolve or reach an agreement & To look after someone or something \\
\hline 25. Steady & Something that is firm or stable & Someone who is laid back or relaxed \\
\hline 26. One & The first numerical digit & Confirmation to a statement \\
\hline 27. Stoned & $\begin{array}{l}\text { A person who is drunk or under the } \\
\text { influence of drugs }\end{array}$ & To describe someone who looks lifeless \\
\hline 28. Tackle & An act of seizing while playing ball & To approach and flirt with an individual \\
\hline 29. Banana & $\begin{array}{l}\text { A long, curved, fruit with yellow skin when } \\
\text { ripe }\end{array}$ & $\begin{array}{l}\text { A Chinese who does not know Chinese } \\
\text { language }\end{array}$ \\
\hline 30. Pattern & Repeated decorative designs & $\begin{array}{l}\text { A person who acts in various kinds of unusual } \\
\text { behaviour }\end{array}$ \\
\hline 31. Member & $\begin{array}{l}\text { A person, animal or plant belonging to a } \\
\text { particular group }\end{array}$ & A close friend \\
\hline 32. Slang & Colloquial words & Accent \\
\hline 33. Control & $\begin{array}{l}\text { The power to influence or direct people's } \\
\text { behaviour }\end{array}$ & Someone who tries to look good \\
\hline 34. Sound & Vibrations that can be heard through the air & To be reprimanded or scolded \\
\hline 35. Whack & To strike forcefully & To grab or dig in all the food \\
\hline 36. Over & Extending directly upwards & Doing things exceeding what is necessary \\
\hline 37. Budget & $\begin{array}{l}\text { An estimate of income and expenditure for a } \\
\text { set period of time }\end{array}$ & To reckon or a person full of act and pretense \\
\hline 38. Onion & A swollen edible bulb used as vegetable & Someone, usually a women who likes to gossip \\
\hline 39. Aliens & $\begin{array}{l}\text { A hypothetical being from another world or } \\
\text { a foreigner }\end{array}$ & Foreign immigrants \\
\hline
\end{tabular}




\begin{tabular}{|l|l|l|}
\hline 40. Aeroplane & A powered flying vehicle & To hurl at stander-uppers/feeling irritated \\
\hline 41. Bang & $\begin{array}{l}\text { To strike or to put down something } \\
\text { forcefully and noisily }\end{array}$ & To criticise \\
\hline
\end{tabular}

Source: Yen, 1990; Menon, 2003; Baskaran, 2005; Azli, 2010; Hajar, 2011; Azirah \& Tan, 2012; Thirusanku \& Melor, 2012; Top 10 Slangs Only Malaysians Would Say (2015), 10 English Words That Have Been Completely Bastardized by Malaysians (2015), 15 Malaysian Slang Words to Help You Speak Like a Local (2017), 10 English Words Only Malaysians Will Understand (2017), 60 Bahasa Rojak Every Malaysian Will Know (2018), and 51 Slangs Malaysians Love to Use (2020), 22 Malaysian Slang Words Only Locals Use Like Potong Stim \& Kantoi (2020), 7 Malaysian Slang Words You Must Know (2021); Cambridge Advance Learner's English Dictionary, 2021).

\section{Formalization}

In linguistics, formalization or formalized language refers to artificial language for which there is a precise formal definition of the class of expressions in the language and an interpretation of the meaning or sense of these expressions (Stoy, 1977). According to this researcher, the description of the expressions of a formalized language and the connections between them, constitute the syntax of a language while the exposition of the meaning of the expressions relates closely with the semantics of the language.

Thus, to give a formalized language is a matter of constructing its syntax and indicating its semantics which is why in a formalized language, one often means just its syntax and the possible semantics are called interpretations (Stoy, 1977). In the ME context of semantic shift however, this term is described as the use of formal words in informal context. In the ME variety, due to matters of collocational confusion, many Malaysian speakers tend to use more formal words in an informal context (Baskaran, 2005). These words are listed in Table 4 below.

Table 4: Formalization of nativised English lexemes in Malaysian English

\begin{tabular}{|c|l|l|}
\hline Words & \multicolumn{1}{|c|}{ Native Meanings } & \multicolumn{1}{c|}{ Informal Meanings/Context } \\
\hline 1. Furnish & $\begin{array}{l}\text { A house provided with furniture and } \\
\text { fittings or to supply someone with } \\
\text { something }\end{array}$ & $\begin{array}{l}\text { Used in the context of informal letters by asking } \\
\text { a friend to provide more detailed information }\end{array}$ \\
\hline 2. Witness & $\begin{array}{l}\text { A person who sees an event, typically a } \\
\text { crime or an accident }\end{array}$ & $\begin{array}{l}\text { Used in the context of a friend asking whether } \\
\text { they have seen the accident or not }\end{array}$ \\
\hline 3. Srutinize & To inspect closely and thoroughly & Used instead of the less informal - examine \\
\hline 4. Residence & $\begin{array}{l}\text { A person's home, especially a large and } \\
\text { impressive one }\end{array}$ & Used instead of the less informal - house \\
\hline 5. Cured & $\begin{array}{l}\text { Relief from symptoms of a disease or } \\
\text { condition }\end{array}$ & Used instead of the less informal - healed \\
\hline 6. Box & $\begin{array}{l}\text { A container with flat base and sides and } \\
\text { has a lid }\end{array}$ & Used to describe hitting someone \\
\hline 7. Shifting & Changing, especially unpredictably & $\begin{array}{l}\text { Used in the context of someone moving, } \\
\text { specifically to a new house }\end{array}$ \\
\hline
\end{tabular}

Source: Yen, 1990; Menon, 2003; Baskaran, 2005; Azirah \& Tan, 2012; Cambridge Advance Learner's English Dictionary, 2021.

\section{Directional Reversal}


The word 'reverse' or 'reversal' is often used to refer to a change in the opposite direction. The concept of change in the opposite direction is also applied in the linguistic term for directional reverse. ME speakers sometimes use certain lexemes in the reverse direction, commonly seen and heard in verb pairs such as 'go' as 'to come' (Baskaran, 2005). This phenomenon is interesting and unique as the semantic shift is caused by the interference of other spoken languages in Malaysia.

Another example is in the confusion between 'lend' and 'borrow' due to the absence of two separate lexemes in the local language. In Malay for instance, the meanings of both words can be communicated through one word, resulting in the inability among some speakers in distinguishing each set of reciprocal verbs (Menon, 2003). Other words in this category are presented in Table 5 below.

Table 5: Directional Reversal of nativised English lexemes in Malaysian English

\begin{tabular}{|c|c|c|}
\hline Words & $\begin{array}{l}\text { Native Meanings } \\
\end{array}$ & Reversed Meanings \\
\hline 1. Lend & To grant someone the use of something & To borrow \\
\hline 2. Borrow & To take and use something that belongs to someone else & To lend \\
\hline 3. Go & To move from one place to another & To come \\
\hline 4. Bring & To take or go with someone or something to a place & To take \\
\hline 5. Take & To lay hold of something with one's hands & To bring or to send \\
\hline 6. Fetch & To go for and bring back someone or something for someone & To take \\
\hline
\end{tabular}

Source: Yen, 1990; Menon, 2003; Baskaran, 2005; Azirah \& Tan, 2012; Cambridge Advance Learner's English Dictionary, 2021.

\section{College Colloquialism}

Rooted deeply in the campus culture today, is a language that may seem foreign to others living outside of the campus bubble. Numerous studies on the lexicon of youth language specifically among college students shows that the language spoken among their peers is quite different than the language they use with non-college students as there is a high amount of extremely informal words and expressions being used by the group (Firooz \& Noraini, 2014).

The researchers conducted a study on the use of American slang among undergraduate students of a public university in Malaysia and found abbreviated words such as 'gonna', 'gotta', 'pic', 'LOL', 'B4N', 'BRB', ' $L O L$ ' and ' $A S A P$ ' as some of the most frequent college colloquialism used by Malaysian undergraduates. Among these English lexemes are words that have been nativised informally by the student population. Instances of semantic shift among nativised English lexemes in ME in terms of college colloquialism are clippings which are words that have been shortened over time, as presented in Table 6.

Table 6: College Colloquialism of nativised English lexemes in Malaysian English

\begin{tabular}{|ll|l|l|}
\hline \multicolumn{1}{|c|}{ Words } & \multicolumn{1}{|c|}{ Native Meanings } & \multicolumn{1}{c|}{ Informal Meanings/Context } \\
\hline 1. & Frustrated & Feelings of distress and annoyance & Same meaning but used as 'frus' \\
\hline 2. & Sabotage & Deliberate destroy, damage or obstruct & Same meaning but used as 'sabo' \\
\hline 3. & Economics & A branch of knowledge concerned with the production, & Same meaning but used as 'econ' \\
\hline
\end{tabular}


International Journal of Modern Languages and Applied Linguistics e-ISSN: 2600-7266

\begin{tabular}{|r|l|l|}
\hline & consumption and transfer of wealth & \\
\hline 4. Bookworm & A person who enjoys reading & $\begin{array}{l}\text { A person who is studious and very } \\
\text { hard working }\end{array}$ \\
\hline 5. Mugger & $\begin{array}{l}\text { A person who attacks and robs another in a public } \\
\text { place }\end{array}$ & $\begin{array}{l}\text { A person who is studious and very } \\
\text { hard working }\end{array}$ \\
\hline 6. Fantastic & Extraordinarily good or attractive & Same meaning but used as 'fantas' \\
\hline
\end{tabular}

Source: Yen, 1990; Menon, 2003; Baskaran, 2005; Azirah \& Tan, 2012; Cambridge Advance Learner's English Dictionary, 2021.

\section{Methodology}

The main objective of the study is to identify frequently used nativised English lexemes in ME as well as to examine these lexemes' current meanings in the Malaysian context. The study employs a descriptive crosssectional survey approach, using questionnaires to collect data. The questionnaire was designed using a webbased online platform called surveymonkey.com with four main parts and seven questions.

In the introduction of the questionnaire, a brief information on the definition and examples of nativised English lexemes in ME were provided to avoid any confusion among respondents between what is meant by ME meanings and Standard English meanings.

The four parts are as follows: 1) demographic information (four questions - age, gender, race/ethnicity, and English as first or second language); 2) respondents' response on frequently used nativised English lexemes in $\mathrm{ME}$ in their daily/informal communication (one question and 88 words to be ticked in the form of checkboxes); 3) a list of meanings and examples in the form of conversational sentences for each nativised English lexemes in $\mathrm{ME}$ to which respondents choose to agree or disagree with the localised meanings given (one question and 88 words with meanings and examples); and 4) a comment section where respondents are encouraged to provide their knowledge or opinion of the meanings of the words that they did not agree with.

The 88 words used in part 2 of the questionnaire were derived from several past studies on ME lexis (Yen, 1990; Menon, 2003; Baskaran, 2005; Azli, 2010; Hajar, 2011; Azirah and Tan, 2012; Thirusanku and Melor, 2012), as well as from several current local websites and blogs including Top 10 Slangs Only Malaysians Would Say (2015), 10 English Words That Have Been Completely Bastardized by Malaysians (2015), 15 Malaysian Slang Words to Help You Speak Like a Local (2017), 10 English Words Only Malaysians Will Understand (2017), 60 Bahasa Rojak Every Malaysian Will Know (2018), and 51 Slangs Malaysians Love to Use (2020), 22 Malaysian Slang Words Only Locals Use Like Potong Stim \& Kantoi (2020), and 7 Malaysian Slang Words You Must Know (2021).

The target participants of the survey are Malaysians. The selection of the participants was based on a probability sampling technique through the distribution of questionnaires and various online and social media platforms such as WhatsApp; Facebook and emails. In total, 100 respondents participated in the survey that was carried out. Majority of the respondents were between 18 to 34 years old. Of the 100 respondents, 12 claimed 
Nur Fatima Wahida Mohd Nasir

Nativised English Lexemes and Semantic Shift in Malaysian English

that English was their first language while the remaining 88 claimed English as their second language.

\section{Results}

\section{Frequently used nativised English lexemes in Malaysian English}

The results on the percentage of usage of 88 nativised English lexemes in ME that were surveyed in the study are presented in Table 7. The percentage of occurrence of each word is presented from highest to lowest.

Table 7: Percentage of frequently used nativised English lexemes in Malaysian English

\begin{tabular}{|c|c|c|c|}
\hline Lexemes & Percentage of usage $(\%)$ & Lexemes & Percentage of usage $(\%)$ \\
\hline 1. Call & 89 & 45. Banana & 47 \\
\hline 2. Students & 85 & 46. Terror & 46 \\
\hline 3. Aunty & 78 & 47. Onion & 45 \\
\hline 4. Member & 77 & 48. Tackle & 44 \\
\hline 5. Open & 76 & 49. Pattern & 44 \\
\hline 6. Uncle & 75 & 50. Frust & 42 \\
\hline 7. $\quad$ Sleep & 75 & 51. Chop & 41 \\
\hline 8. Go & 75 & 52. Shillings & 40 \\
\hline 9. Tupperware & 74 & 53. Coffee Shop & 39 \\
\hline 10. Cartoon & 72 & 54. Aliens & 38 \\
\hline 11. On & 72 & 55. Hubby & 36 \\
\hline 12. Settle & 72 & 56. Aeroplan & 36 \\
\hline 13. Tuition & 71 & 57. Residence & 34 \\
\hline 14. Best & 70 & 58. Beat & 33 \\
\hline 15. Control & 70 & 59. Bang & 33 \\
\hline 16. Boss & 69 & 60. Lend & 33 \\
\hline 17. Bro & 68 & 61. Squat & 32 \\
\hline 18. Outstation & 67 & 62. Fetch & 32 \\
\hline 19. Follow & 67 & 63. Theatre & 29 \\
\hline 20. Power & 66 & 64. Bookworm & 29 \\
\hline 21. Sound & 65 & 65. Estate & 28 \\
\hline 22. Budget & 65 & 66. Cured & 28 \\
\hline 23. See & 64 & 67. Witness & 27 \\
\hline 24. Over & 64 & 68. Chase & 25 \\
\hline 25. Action & 62 & 69. Windy & 25 \\
\hline 26. Blur & 61 & 70. Spoilt & 25 \\
\hline 27. Kids & 60 & 71. Fellow & 25 \\
\hline 28. One & 60 & 72. Stoned & 23 \\
\hline 29. Tackle & 60 & 73. Furnish & 23 \\
\hline 30. Cut & 58 & 74. Occupy & 22 \\
\hline 31. Partner & 58 & 75. Compound & 22 \\
\hline 32. Roger & 58 & 76. Liaise & 21 \\
\hline 33. Steady & 58 & 77. Shifting & 19 \\
\hline 34. Spend & 56 & 78. Econ & 17 \\
\hline 35. Cable & 56 & 79. Scrutinize & 15 \\
\hline 36. Bungalow & 53 & 80. Heaty & 14 \\
\hline 37. Reduce & 53 & 81. Whack & 12 \\
\hline 38. Change & 53 & 82. Sabo & 12 \\
\hline 39. Box & 52 & 83. Mugger & 9 \\
\hline 40. Line & 51 & 84. Flick & 8 \\
\hline
\end{tabular}




\begin{tabular}{|l|l|l|c|}
\hline 41. Bring & 50 & 85. Fantas & 6 \\
\hline 42. Borrow & 49 & 86. Fly & 3 \\
\hline 43. Slang & 48 & 87. Keep & 2 \\
\hline 44. Slumber & 47 & 88. Fix & 2 \\
\hline
\end{tabular}

The table above shows that the highest percentage of usage is $89 \%$ from the word "call" and the lowest is $2 \%$ from the word 'fix'. Based on Nation's statistical validity for vocabulary size, a total number of 88 words would mean that about 30 to 45 running words would be sufficient to be represented in a vocabulary test.

Thus, for other studies to test the vocabulary knowledge of nativised English lexemes among various social domains in Malaysia, 30 to 45 of these most frequently used words in ME can be used because of its popularity and familiarity in the speech community. Table 7 also interprets that the remaining words such as; fantas (6\%), fly (3\%), keep (2\%), fix (2\%) and others may be considered as less popular, less familiar or rarely used nativised English lexemes in Malaysia.

\section{Agreements on the current meanings of nativised English lexemes in Malaysian English}

The results on the frequency of agreements of 88 nativised English lexemes in ME that were surveyed in the study are presented in Table 8. The frequency of occurrence of each word is presented from highest to lowest.

Table 8: Frequency of agreements for each nativised English lexemes in Malaysian English

\begin{tabular}{|c|c|c|c|}
\hline Lexemes & Frequency of agreements & Lexemes & Frequency of agreements \\
\hline 1. Aunty & 89 & 45. Witness & 58 \\
\hline 2. Uncle & 87 & 46. Bookworm & 58 \\
\hline 3. $\quad$ Students & 87 & 47. Fellow & 57 \\
\hline $\begin{array}{ll}\text { 4. } & \text { Tupperware }\end{array}$ & 84 & 48. Open & 56 \\
\hline 5. Outstation & 84 & 49. Shillings & 56 \\
\hline 6. Tuition & 84 & 50. Liaise & 55 \\
\hline 7. Kids & 84 & 51. Chase & 55 \\
\hline 8. Sleep & 83 & 52. Coffee shop & 55 \\
\hline 9. Call & 82 & 53. Line & 55 \\
\hline 10. Best & 81 & 54. Borrow & 54 \\
\hline 11. Bungalow & 80 & 55. Lend & 52 \\
\hline 12. Power & 80 & 56. Cut & 50 \\
\hline 13. On & 80 & 57. Theatre & 47 \\
\hline 14. Bro & 79 & 58. Compound & 47 \\
\hline 15. Beat & 78 & 59. Onion & 46 \\
\hline 16. Follow & 78 & 60. Occupy & 45 \\
\hline 17. Roger & 76 & 61. Spend & 45 \\
\hline 18. Blur & 74 & 62. Chop & 45 \\
\hline 19. Settle & 74 & 63. Stoned & 45 \\
\hline 20. Steady & 74 & 64. Shifting & 44 \\
\hline 21. Slang & 74 & 65. Econ & 40 \\
\hline 22. Hubby & 73 & 66. Cartoon & 38 \\
\hline 23. Partner & 73 & 67. Cured & 38 \\
\hline 24. Cable & 73 & 68. Spoilt & 37 \\
\hline 25. Over & 73 & 69. Scrutinize & 35 \\
\hline 26. Member & 72 & 70. Aliens & 34 \\
\hline
\end{tabular}


Nur Fatima Wahida Mohd Nasir

Nativised English Lexemes and Semantic Shift in Malaysian English

\begin{tabular}{|l|l|l|c|}
\hline 27. Control & 72 & 71. Sabo & 34 \\
\hline 28. Terror & 71 & 72. Box & 32 \\
\hline 29. Change & 70 & 73. Banana & 29 \\
\hline 30. Go & 70 & 74. Bang & 28 \\
\hline 31. Frust & 70 & 75. Heaty & 28 \\
\hline 32. Boss & 68 & 76. Sound & 28 \\
\hline 33. Action & 68 & 77. Whack & 26 \\
\hline 34. Fetch & 67 & 78. Squat & 25 \\
\hline 35. Slumber & 66 & 79. Mugger & 23 \\
\hline 36. Tackle & 66 & 80. Windy & 23 \\
\hline 37. Budget & 66 & 81. Flick & 22 \\
\hline 38. Take & 65 & 82. Pattern & 3 \\
\hline 39. Bring & 64 & 83. Furnish & 2 \\
\hline 40. See & 62 & 84. Fantas & 2 \\
\hline 41. Reduce & 61 & 85. Aeroplan & 1 \\
\hline 42. One & 61 & 86. Keep & \\
\hline 43. Estate & 59 & 87. Fly & \\
\hline 44. Residence & 59 & 88. Fix & \\
\hline
\end{tabular}

Data from Table 8 shows that the highest frequency on the most agreed meaning from this list of lexemes is the word 'aunty' with a total number of 89 people (96.74\%). According to the Standard English meaning, 'aunty' is commonly referred to women with family relations, specifically the sister of one's mother or father, or the wife of one's uncle (Cambridge English Dictionary, 2021). In the Malaysian culture however, 'aunty' has long been recognized as the reference of an older woman, regardless whether that person is a family member or not.

According to a study by Zhia (2015), the phenomenon of 'aunty' and 'uncle' is said to possibly be due to the migration of Chinese people to Malaya back in the $15^{\text {th }}$ century, bringing and adapting their culture to the indigenous people during the time. For the Chinese, it is common that older people would be greeted as shushu (uncle) and shen-shen (aunty). To adapt the mix of ethnicities in Malaysia, the title eventually conformed to the English lexeme; 'aunty' and 'uncle' which plays an extremely important role in the sense of social adaptability and social connectedness within the Malaysian context.

Based on these facts, it is not surprising why the word 'aunty' was agreed by $96.74 \%$ of the respondents and 'uncle' as much as $95.60 \%$. This also proves that in the Malaysian context, certain ME lexemes have shifted to become much more than just words of expressions but have become dominant words that reflect the uniqueness and cultural identity of Malaysians as mentioned by Yamaguchi and Deterding (2016). In this case, by agreeing with the word 'aunty', respondents of the survey have somehow proven that they are very much familiar with the cultural norms in Malaysia.

Results of the data above also reveal that several words in which respondents agreed to the meanings also reflect the high percentage of usage as well such as; aunty, uncle, tupperware, sleep, students, outstation, on, frust, power, bro, follow, and several others. This is very much logical according to researchers of vocabulary Copyright (C) The Author(s). All Rights Reserved 
tests such as Schmitt (2008) who states that in order to use a word effectively, one should also know a great deal about the meanings of the words and its associations. Nation (2001) also claims in his framework of vocabulary knowledge that knowledge of a word includes three kinds which are knowledge of form, knowledge of meaning, and knowledge of use.

However, the study also discovered several words that were mostly agreed by respondents but were not listed under the most frequently used nativised English lexemes in ME. These words include; hubby, fetch, witness, bookworm, fellow and several others. According to researchers such as Yule (2010) this situation happens simply due to human's natural response towards language choice or word choice, indicating that although a person knows and understands the definition of a particular word, this does not necessarily mean that the person would often use it. In parallel to this statement, Hajar (2006) further explains that word choice made by speakers in the Malaysian context has proven to function more than just filling in linguistic gaps, but rather a choice to express forms of cultural and individualistic identity.

\section{Disagreements on the current meanings of nativised English lexemes in Malaysian English}

In the last part of this research, respondents were required to provide their knowledge or opinions on the meanings of the words in which they did not agree with by describing or explaining the meanings according to their understandings. Based on the data obtained, only 9 respondents gave their comments in the openended question section for several nativised English lexemes in which they did not agree with the current meanings provided in the survey. These respondents' comments are shown below.

1. Respondent 6: a) opens means switch on

b) call means invite

2. Respondent 14: a) cured means full recovery

3. Respondent 16: a) cut is like to cut onions

b) spend is like to spend money wisely

4. Respondent 28: a) cut is when we normally use knife

b) open is for doors or books

5. Respondent 35: a) I usually say switch on the light instead of open

b) pattern I thought is actually for design on something

6. Respondent 37: a) instead of 'theatre' I'm simply use word 'movie' to refer as a cinema hall

7. Respondent 51: a) my definition of the word 'cut' is also to throw out toxicity, e.g., "dude, just cut him/her out of your life, you don't deserve that kind of treatment that he/she gave you"

b) cartoon to me means animation

c) see also means 'I told you so', e.g., "see la, I told you already...now you still do the same thing?"

d) Whack can mean the worst, e.g., "bruh the song is really whack for real, there's no vibe to it" and can also mean to smack

e) Alien can mean does not fit in besides foreign, e.g., "I feel like I'm an alien when I'm with a lot of people, they just different than I am"

8. Respondent 57: a) some of the words did not come from an English origin per say

9. Respondent 76: a) Windy and heaty usually used for weather 


\section{Nur Fatima Wahida Mohd Nasir \\ Nativised English Lexemes and Semantic Shift in Malaysian English}

From the above comments given by the 9 respondents, it is obvious that some of the comments did not relate to their understanding of the words in which they did not agree with such as respondent $35-1,37$, and 57 who gave statements rather than explanations. It is also noticeable here, that several respondents were confused as some of them gave their understandings on the meanings of the words based on the Standard English meanings.

This can be seen from respondent 16 who gave examples of the words 'cut' and 'spend' in sentences that were semantically logical in the Standard English language. Another example is from respondent 28. Instead of providing definitions of the words 'cut' and 'open' based on the Malaysian context, the person stated the definition of both these words based on the Standard English meanings.

This is the same for respondent 35 who described the word 'pattern' as related to designs which is similar to the Standard English meaning and respondent 51 who referred 'cartoon' to animations, 'whack' for smacking and 'see' as another way of saying, 'I told you so'. The three meanings above given by respondent 51 are related to the Standard English meanings and associations.

Respondent 76 also responded confusingly stating that the words 'windy' and 'heaty' are commonly used for weather which is similar to the Standard English meaning. Respondent 6 had also made an error in his response as the person explained the words 'open' and 'call' similarly to the Malaysian meanings provided in the question.

Thus, the remaining comments that were considered reasonable and logical to be analysed is from respondent 14 who explained that the word 'cured' could also mean 'full recovery' in ME and respondent 51 who mentioned that the word 'cut' could also mean 'to throw out toxicity'. Besides that, respondent 51 further explained that the word 'whack' could also mean 'the worst' while 'alien' could also be related to 'not fitting in'.

\section{Discussion and Conclusions}

Based on the data above, this research concludes that all 88 nativised English lexemes in ME listed in this survey can be regarded as valid and reliable. This is because although literature shows that there has been a lack of current study in the area, results from the findings of this study indirectly indicates that all 88 nativised English lexemes do exist in the variety and are used within the speech community based on different frequencies.

In addition, words that were found in current, local websites of the Malaysian community such as Top 10 Slangs Only Malaysians Would Say (2015), 15 Malaysian Slang Words to Help You Speak Like a Local (2017) and a few more mentioned in the study also prove to be valid and reliable as results show that a lot of the words ticked and agreed by respondents came from these websites including words like; power, settle, action, 
International Journal of Modern Languages and Applied Linguistics e-ISSN: 2600-7266

member, tupperware, cartoon, on, sound, budget, over, steady and several others.

The study also concludes that in ME, the meanings of nativised English words may evolve from time to time in order to adapt to the cultural environment and current trending topics among the citizens in Malaysia. Hence, in order to further explore on the development of nativised English lexemes in ME, this study proposes that more investigation should be conducted in terms of its use and competencies among various social groups in Malaysia.

Findings also show that among the six sub-categories under English lexicalization in ME from Azirah and Tan (2012), the most frequently used nativised English lexemes in ME were found in the category of informalization. The result is on par with Fairclough's (2003) statement which explained that informalization is the most common linguistic and functional style of speech for casual communication and is characterized by a wide range of usage of interjections and other expressive devices along with rapid changes in lexicon.

In the Malaysian context, the data is also parallel with Baskaran's (2005) study who stated that many of the lexemes articulated by ME speakers are mostly used within the spoken mesolect level and tend to be informal substitutions of Standard English words where it is common to find a profusion of lexemes indicating a more informal style and register in ME. Moreover, according to a research by Leech, Hundt, Mair, and Smith (2010), informalization has been well documented in the language of media where in news reportage for example has seen a definite trend away from the traditional written style and is leaning towards a more spontaneous directness.

This could be the reason why remaining words that were not categorized as frequently used nativised English lexemes in ME, were found to be less popular or familiar among the respondents. Two past research studies that agree with this phenomenon in Malaysia is from Lowenberg (1991) and Gill (2002) who explained that the reason why certain nativised English lexemes may not be popular or less used by Malaysians is mainly because these words are not actively being 'marketed' or less advertised in the mass media such as through television dramas, commercial breaks or through radio stations and even through political speeches and 'banner words' which are terms that are filled with political and cultural significance in public discourse.

A more recent study by Firooz and Noraini (2014) showed that ME jargons and slangs, which also include nativised English lexemes are widely being popularized through social media since it is regarded as an acceptable formal and informal way of communication, and can be understood by most people and attract more attention. Hence, the frequent usage of nativised English lexemes through social media could also become one of the factors to why some words are being used more than others.

Lastly, this research also concludes that based on the high frequency/percentage of agreements on the current meanings and examples of the data, it can be confirmed that in general, all 88 nativised English lexemes in 


\section{Nur Fatima Wahida Mohd Nasir \\ Nativised English Lexemes and Semantic Shift in Malaysian English}

ME listed in this study are considered to have the correct, current meanings up to the year 2021. Hence, these words and meanings can be used for other researchers to conduct further studies in the area especially on nativised English lexemes that could possibly have wider and deeper meanings in ME.

\section{References}

Azirah, H., \& Tan, R. (2012). Malaysian English. English in Southeast Asia: features, policy and language in use. 42.

Azli, N. L. (2010). A Corpus-based Study of Lexical Creativity in Spoken Mesolectal Variety of Malaysian English. Unpublished MA thesis. School of Humanities, Universiti Sains Malaysia.

Baker, P., \& Ellece, S. (2011). Key Terms in Discourse Analysis. Continuum.

Baskaran, L. (2005). A Malaysian English Primer. Kuala Lumpur. University Malaya Press.

Cambridge Advanced Learner's English Dictionary (2021). Cambridge University Press.

Crowley, T., \& Bowern, C. (2010). An introduction to historical linguistics. Oxford University Press, $4^{\text {th }}$ ed.

Crystal, D. (2006). How language works. Overlook.

David, M. K., (2000). The language of Malaysian youth - an exploratory study. English is an Asian Language: The Malaysian Context. Kuala Lumpur (pp. 64-72).

Fairclough, N. (2003). Analyzing discourse. textual analysis for social research. Routledge. London \& New York.

Firooz, N., \& Noraini, I. (2014). Popularity and familiarity of slang among ESL students. Journal of Applied Sciences. Volume 14. Issue 24 (3585-3590).

Gill, S. K. (2002). International communication: English language challenges for Malaysia. Serdang: Universiti Putra Malaysia Press.

Grandy, R. E. (2012). Semantic fields, prototypes, and the lexicon. Frames, Fields, and Contrasts: New Essays in Semantic and Lexical Organization. Routledge. pp. 103-122.

Grzega, J., \& Schöner, M. (2007). English and general historical lexicology: materials for onomasiology seminars. Eichstätt: Universität.

Hajar, A. R. (2006). The evolution of Malaysian English: influences from within. Biennial Conference of the Asian Studies Association of Australia. University of Wollongong, Australia.

Hajar, A. R. (2014). Malaysian English lexis: postcolonial and beyond. In English in Malaysia: Postcolonial and Beyond. Peter Lang.

Jackson, H., \& Amvela, E., Z. (2000). Words, meaning, and vocabulary: an introduction to modern English lexicology. New York: Cromwell Press.

Kachru, B. (2006). English: world Englishes. In Encyclopedia of Language \& Linguistics.

Kadir, A., Maros, Z., \& A. Hamid, M. B., (2013). Linguistic features in the online discussion forums. International Journal of Social Science and Humanity.

Katamba, F. (2004). English words: structure, history, usage. Routledge.

Lakoff, G., \& Johnson, M. (2003). Metaphors we live by. Chicago and London: The University of Chicago Press.

Lalor, T. (2007). That's so gay: a contemporary use of gay in Australian English. Australian Journal of Linguistics. 27 (200): 147-173.

Leech, G., Hundt, M., Mair, C., \& Smith, N. (2010). Change in contemporary English: a grammatical study. Cambridge University Press.

Lowenberg, P. H. (1991). Variation in Malaysian English: the pragmatics of languages in contact. English Around the World. Sociolinguistic Perspectives. 364-375.

Menon, D. (2003). Non-native features in the lexis of Malaysian English. University of Malaya.

Millward, C. M., \& Hayes, M. (2012). A biography of the English language. Wadsworth, $3^{\text {rd }}$ ed.

Nation, I. S. P. (2001). Learning vocabulary in another language. Cambridge: Cambridge University Press. Pillai, S., (2013). The mouton world atlas of variation in English, chapter: colloquial Malaysian English. 
Publisher: Mouton de Gruyter, Editors: Kortmann B, Lunkenheimer K, pp.573-584.

Ruano-García, J. (2010). Early modern Northern English lexis: a literary corpus-based study. Bern: Peter Lang.

Rusli, M. F., Aziz, M. A., Aris, S. R. S., Jasri, N. A., \& Maskat, R. (2018). Understanding Malaysian English (Manglish) jargon in social media. Journal of Fundamental and Applied Sciences. 10 (pp. 116-125).

Schmitt, N. (2008). Review article: Instructed second language vocabulary learning. Language Teaching Research. 12, 329- 363.

Steinmetz, S. (2008). Semantic antics: how and why words change meanings. Random House.

Stoy, E. (1977). Denotational semantics: the scott-strachey approach to programming language theory. M.I.T.

Thirusanku, J., \& Melor, M. Y. (2012). The many faces of Malaysian English. International Scholarly Research Network. ISRN Education.

Thurairaj, S., Hoon, E. P., Roy, S. S., \& Fong, P. W. (2015). Reflections of students' language in social networking sites: making or marring academic English. Electronic Journal of e-Learning. Volume 13. Issue 4 (pp 302-316).

Traugott, C. E. (2006). Semantic change: bleaching, strengthening, narrowing, extension. Encyclopedia of Language and Linguistics Second Edition. 11, 124- 130.

Traugott, C. E., \& Dasher, B. R. (2002). Regularity in semantic change. Cambridge University Press.

Vanhove, M. (2008). From polysemy to semantic change: towards a typology of lexical semantic associations. Studies in Language Companion Series. Amsterdam, New York: Benjamins.

Yamaguchi, T., \& Deterding D. (2016). English in Malaysia: current use and status (1 ed., pp. 25-44).

Yen, E. E. L. (1990). Towards a lexicon of Malaysian English. Unpublished M.A dissertation. Universiti Kebangsaan Malaysia.

Yule, G. (2010). The study of language. Cambridge University Press. Fourth Edition.

Zhia, E. L. (2015). Colloquial Malaysian English: a problem or a cool phenomenon? Masters Dissertation. Master of International Communication and Teaching Languages, Universitat Jaume.

Top 10 Slangs Only Malaysians Would Say (2015). Time Out KL. Retrieved from: https://www.timeout.com/kuala-lumpur/things-to-do/top-10-slangs-only-malaysians-would-say

10 English Words That Have Been Completely Bastardized by Malaysians (2015). Coconuts KL. Retrieved from: https://coconuts.co/kl/features/10-english-words-have-been-completely-bastardised-malaysians/

10 English Words Only Malaysians Will Understand (2017). World of Buzz. Retrieved from: https://worldofbuzz.com/10-english-words-malaysians-will-understand/

15 Malaysian Slang Words to Help You Speak Like a Local (2017). Culture Trip. Retrieved from: https://theculturetrip.com/asia/malaysia/articles/theres-no-doubt-youll-hear-these-15-slang-words-in-malaysia/

60 Bahasa Rojak Every Malaysian Will Know (2018). Shopback; Lifestyle. Retrieved from: https://www.shopback.my/blog/bahasa-rojak-malaysian

22 Malaysian Slang Words Only Locals Use Like Potong Stim \& Kantoi (2020). The Smart Local. Retrieved from: https://thesmartlocal.com/read/malaysian-slang/

51 Slangs Malaysian Love to Use (2020). Ordinary Reviews. Retrieved from: https://www.ordinaryreviews.com/slangs-malaysians-love-to-use

7 Malaysian Slang Words You Must Know (2021). Traveloka. Retrieved from: https://www.traveloka.com/en-sg/explore/tips/7-malaysian-slang-words-must-know/48040 